\title{
Pengembangan Program Penyelarasan strategi Bisnis-TI Badan Pemberdayaan Perempuan dan Keluarga Berencana Provinsi Sumatera Barat
}

\author{
Ruri Juswira \\ Aparatur Sipil Negara Dinas Pemberdayaan Perempuan \\ dan Perlindungan Anak Provinsi Sumatera Barat \\ *Corresponding author, e-mail: uwi_tif02@yahoo.co.id
}

\begin{abstract}
Abstrak-Artikel ini membahas perancangan program untuk meningkatkan kematangan keselarasan strategi bisnis-TI yang berguna untuk mendorong peran Teknologi Informasi dan Komunikasi (TIK) agar dapat mendukung setiap kegiatan Badan Pemberdayaan Perempuan dan Keluarga Berencana Provinsi Sumatera Baratdalam mencapai visi dan misinya. Penelitian ini menggunakan metodologi research and development (RnD) yang digunakan untuk menghasilkan produk dan menguji keefektifan produk tersebut dengan jumlah responden sebanyak 17 orang. Instrument penelitian yang dibuat mengacu pada 6 domain area keselarasan strategi bisnis-TI SAMM Luftman dengan modifikasi sesuai dengan lingkup pemerintahan. Dari 6 domain area tersebut ditemukan 36 faktor penghambat. Hal ini relevan dengan faktor-faktor penghambat hasil penelitian SAMM Luftman. Dari ketiga puluh enam faktor penghambat ditemukan hubungan relasional yang menjadi dasar perancangan program sebagai produk penelitian. Perancangan produk disesuaikan dengan kondisi sekarang dan harapan tingkat keselarasan strategi bisnis-TI yang lebih baik. Setelah melewati uji validasi konsep secara materi/isi dan uji coba konsep secara empiris (praktikalitas dan efektifitas), hasil pengukuran produk tersebut dinilai sangat praktis dan efektif. Terdapat 42 program yang mampu menaikkan tingkat kematangan keselarasan strategi bisnis-TI ke level yang diinginkan.
\end{abstract}

Kata Kunci: Penyelarasan Strategi Bisnis-TI, SAMM-Luftman

\begin{abstract}
This paper discusses program planning for supporting role information communication and technology (ICT) in order to support every BPPr \& KB activity in reaching its vision and mission. This observation use methodology research and development $(\mathrm{RnD})$ which is used to result product and test the effectivity with many responden 17 persons. Instrument of the observation made to 6 domain area allignmnent strategy business-IT SAMM Luftman with proper modification to the goverment environment. From 6 domain area is found that 36 abstacle factors. This relevant to the obstacle result of Luftman observation. From the thirty sixth obstacle factors found the relational connection to be basic of program planning as observation product. Designing product is proper to current condition and expectation of allignment business-IT strategy that is better. After passing to the validation test as matery and content trial and error concept empirically (practicality and effectivity), result of product measurement is considered very practice and effective. There are 42 programs that capable to enhance allignment maturity level Bussiness-IT strategy to the wanted level.
\end{abstract}

Key Words: Allignment Bussiness-IT Strategy, SAMM-Luftman

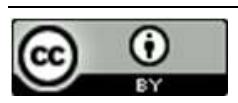

This is an open access article distributed under the Creative Commons 4.0 Attribution License, which permits unrestricted use, distribution, and reproduction in any medium, provided the original work is properly cited. C2018 by Author and Universitas Negeri Padang

\section{Pendahuluan}

Kajian ini berangkat dari masalah penggunaan Teknologi Informasi dan Komunikasi (TIK) yang kurang berpengaruh terhadap peningkatan kinerja bagi suatu organisasi. TIK seyogianya juga digunakan oleh pemerintah untuk menunjang perencanaan pembangunan daerah, mengingat EGovernment hadir sebagai bentuk pemanfaatan TIK yang dapat meningkatkan hubungan antara Pemerintah, masyarakat, kalangan bisnis maupun 
antar sesama pemerintah.

Badan Pemberdayaan Perempuan dan Keluarga Berencana (BPPr \& KB) merupakan Satuan Kerja Perangkat Daerah Provinsi Sumatera Barat yang mempunyai tugas pokok melaksanakan penyusunan dan pelaksanaan kebijakan daerah bidang Pemberdayaan Perempuan dan Keluarga Berencana telah menyusun Perencanaan Strategis tahun 2016 - 2021 dengan berpedoman pada pokok-pokok kebijakan dan arah pembangunan daerah yang tertuang dalam RPJMD Provinsi Sumatera Barat Tahun 2016 - 2021.

Dokumen Rencana Strategis (Renstra) ini merupakan acuan dan arahan bagi BPPr \& KB Provinsi Sumatera Barat dalam merencanakan dan melaksanakan program Pemberdayaan Perempuan dan Keluarga Berencana periode Tahun 2016 2021 secara menyeluruh, terintegrasi, dan sinergis dalam bidang-bidang yang berada dalam BPPr \& KB Sumatera Barat dan Instansi teknis terkait Pemerintah Provinsi. Hanya saja Rencana Strategis ini belum pernah dilaksanakan pengukuran keselarasan strategi TI dengan strategi Bisnis, guna menghasilkan perubahan rencana strategi yang mendukung pencapaian visi dan misi organisasi.

Penelitian ini bertujuan untuk memperoleh: (a.) Tingkat kematangan Penyelarasan Strategi Sistem/ Teknologi Informasi dan Bisnis BPPr dan KB Prov. Sumbar. (b.) Proses pengembangan program untuk menyelaraskan strategi Bisnis-TI pada BPPr \& KB. (c.) Dokumen Rencana Kerja (Renja) yang berisi program/kegiatan untuk Badan Pemberdayaan Perempuan dan KB Provinsi Sumatera Barat sehingga dapat meningkatkan level keselarasan strategi Bisnis-TI nya.

\section{Studi Pustaka}

Penulisan kajian teori dalam penelitian ini, akan dijabarkan dan diurutkan berdasarkan perumusan masalah dalam penelitian. Teori-teori tersebut akan mendukung identifikasi permasalahan dalam penelitian dan analisis terhadap penyelarasan strategi Bisnis dan TI yang akan menghasilkan keluaran (output) berupa usulan perbaikan rencana strategis Badan Pemberdayaan Perempuan dan Keluarga Berencana (BPPr \& KB) Provinsi Sumatera Barat.

Menurut Bernard H. Boar, Strategi adalah hal yang memuat tentang apa saja yang harus diselesaikan/ dicapai dan apa tujuan dari penyelesaian/pencapaian hal-hal tersebut. [1] atau dengan kata lain hal apa saja yang harus dicapai dan bagaimana cara mencapainya. Dari pengertian tersebut, dapat kita simpulkan bahwa strategi merupakan kumpulan yang terdiri dari penentuan target dan maksud kenapa target itu dibuat demi menjaga daya saing dan keberlanjutan jalannya bisnis suatu organisasi. Bernard H. Boar menjabarkan komponen strategi sebagaimana yang digambarkan pada gambar 1 berikut ini:

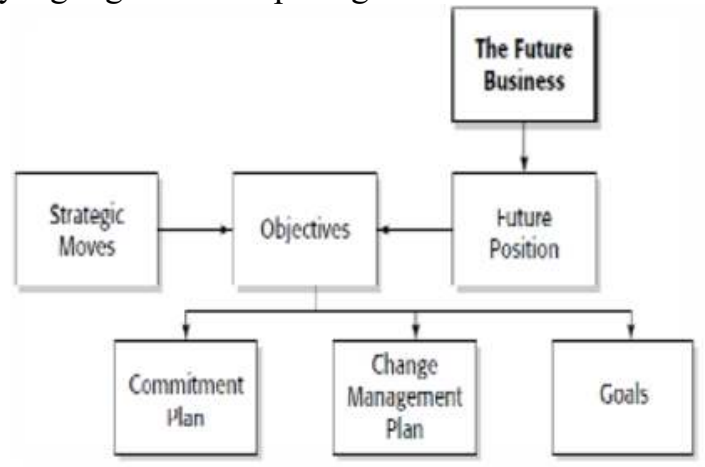

Gambar 1: Strategi bisnis dan organisasi

Komponen tersebut meliputi:

(a.) Kondisi bisnis di masa depan (the future business). Bahwa kondisi bisnis di masa depan harus bisa di defenisikan atau diperkirakan mulai dari saat ini, orang yang mampu berkhayal lebih tinggi secara realistis, akan menjadi orang yang visioner terhadap perencanaan strategi organisasinya.

(b.) Posisi organisasi di masa depan (future position). Setelah dapat memperkirakan kondisi bisnis di masa depan, posisi yang ingin dicapai organisasi di masa depan juga harus ditentukan. Apakah organisasi nantinya diharapkan diposisi puncak atau cukup diposisi kedua.

(c.) Sasaran utama (objectives). Dengan mendefenisikan posisi yang hendak dicapai di masa depan, maka sasaran utama yang bersesuaian dengan posisi yang hendak dicapai dapat didefenisikan pula.

(d.) Target-target jangka pendek (goals). Dengan didefenisikannya sasaran utama, maka target-target jangka pendek sebagai tahapantahapan untuk menuju sasaran utamanya dapat ditentukan untuk lebih meperjelas hal-hal yang harus diraih.

(e.) Langkah-langkah strategis (strategic moves). Yaitu langkah-langkah yang harus dilakukan untuk mencapai target-target jangka pendek.

(f.) Perencanaan manajemen perubahan (change management plan). Perubahan strategi terkadang akan berimbas terhadap perubahan pola kerja organisasi, biasanya akan timbul resistansi/penolakan terhadap perubahan itu. 
Untuk meminimalkan penolakan itulah perlu didefenisikan perencanaan terhadap manajemen perubahan agar tidak terjadi gejolak yang justru kontra produktif terhadap strategi organisasi.

(g.) Perencanaan komitmen (commitment plan). Yaitu sikap dan tindakan yang berkenaan terhadap kredibilitas seluruh anggota organisasi terhadap tujuan yang hendak diraih.

Strategi Bisnis yaitu strategi yang berisi bagaimana proses bisnis organisasi dapat dijalankan secara efektif dan efisien untuk menjalankan suatu organisasi. Secara singkat Turban dan Volino mendefenisikan strategi bisnis sebagai segala sesuatu yang member arah jalannya bisnis. [2]

Secara lebih teknis Turban dan Volino menyatakan strategi teknologi informasi adalah proses pendefenisian tentang informasi, sistem informasi dan arsitektur teknologi informasi apa saja yang dibutuhkan untuk mendukung bisnis. Disamping itu, strategi TI termasuk pendefenisian bagaimana cara agar infrastruktur dan layanan teknologi informasi dapat sampai ke pihak-pihak yang berkepentingan dalam bisnis. [2]

Suatu strategi harus selalu dievaluasi secara periodik atau diubah sesuai perkembangan pasar, karena saat ini perkembangan bisnis dan teknologi selalu berubah mengikuti perubahan waktu dan tren yang ada.

Keberadaan strategi TI dan strategi bisnis telah menjadi hal yang harus dimiliki organisasi saat ini. Agar organisasi dapat memperoleh keuntungan kompetitif dari hal tersebut, strategi TI dan strategi bisnis harus harmonis-selaras, sehingga mampu bersinergi, mendorong organisasi bergerak ke tujuan yang benar secara efektif dan efisien. Isu tentang keselarasan ini telah menjadi prioritas tertinggi dalam sepuluh permasalahan utama dunia manajemen bisnis selama bertahun-tahun. [3-4]

Keselarasan strategis teknologi informasi adalah kombinasi keterkaitan antara semua strategi-strategi unit teknologi informasi, perencanaan, semua proses bisnis, investasiinvestasi dan keputusan-keputusan, untuk mendukung keseluruhan fungsi dan tujuan dari sasaran dan target organisasi. [5] Artinya bahwa keseluruhan organisasi dan fungsi-fungsi unit teknologi informasi seharusnya mendukung secara aktif visi, misi, target dan strategi dari organisasi.

Ada beberapa model kerangka kerja terkait dengan keselarasan strategi bisnis dan TI. Dalam konteks penelitian ini, ada 2 model kerangka kerja yang dibahas yaitu SAM (Strategic
Alignment Model) dan SAMM (Strategic Alignment Maturity Model).

SAM (Strategic Alignment Model), didefenisikan sebagai model kerangka kerja manajemen bisnis dan TI dalam rangka menunjang kesuksesan dari implementasi bisnis, SI/TI dalam komponen infrastruktur pandukung.[6] Model dari kerangka kerja SAM mencakup 4 fokus area/4 kuadran yang mewakili pilihan strategi yang mencakup: strategi bisnis (business strategy), strategi TI (IT Strategy), infrastuktur organisasional dan proses-proses (organizational Infrastructure and processes), infrastruktur SI/TI dan proses-proses (IS/IT infrastructure and processes). Hubungan dari keempat fokus area tersebut. Masing-masing fokus area memiliki 3 komponen, sehingga didapat total ada 12 komponen diperlihatkan pada gambar 2 berikut:

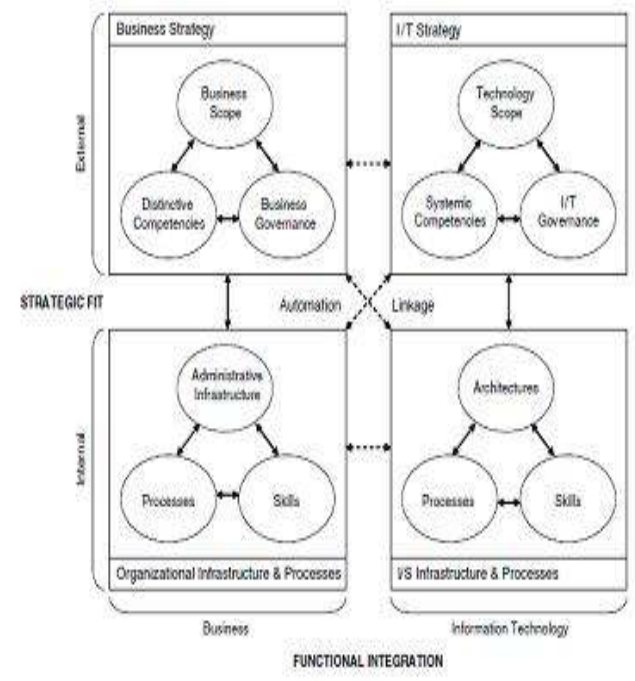

Gambar 2: Model kerangka kerja SAM

SAMM (Strategic Alignment Maturity Model), diperkenalkan oleh Luftman, model SAMM dibuat berdasarkan pengembangan dari 12 komponen pada model SAM Henderson dan Venkatraman dan hasil penelitian Luftman untuk mengidentifikasi faktor-faktor yang menjadi pemicu (enabler) dan penghambat (inhibitor) terhadap keselarasan antara bisnis dengan TI.

Hubungan yang terjadi antara ke 12 komponen tersebut mendefenisikan keselarasan strategi. Luftman berpendapat bahwa kesuksesan organisasi dengan semakin meningkatnya persaingan di pasar global tergantung kepada keharmonisan-keseimbangan dari keempat fokus area (model SAM) yang terdiri dari 12 komponen keselarasan. [7] Keempat fokus area yang dimaksud adalah strategi bisnis, strategi TI, 
infrastruktur organisasi dan proses-proses, dan infrastruktur TI dan proses-proses. Luftman melalui model SAMM, melengkapi model SAM dengan metode untuk mencapai keselarasan strategi, kombinasi dari 12 komponen pada model SAMM dan faktor pemicu dan penghambat keselarasan menghasilkan metode penilaian tingkat kematangan dari keselarasan strategi bisnis dan TI. [8]

Model penilaian terhadap keselarasan strategi TI-Bisnis yang disusun oleh professor Luftman memiliki enam kriteria kematangan [9] dapat dilihat pada gambar 3, yaitu: Komunikasi, pengukuran manfaat/kompetensi, tata kelola, kerjasama, ruang lingkup dan arsitektur serta keahlian.

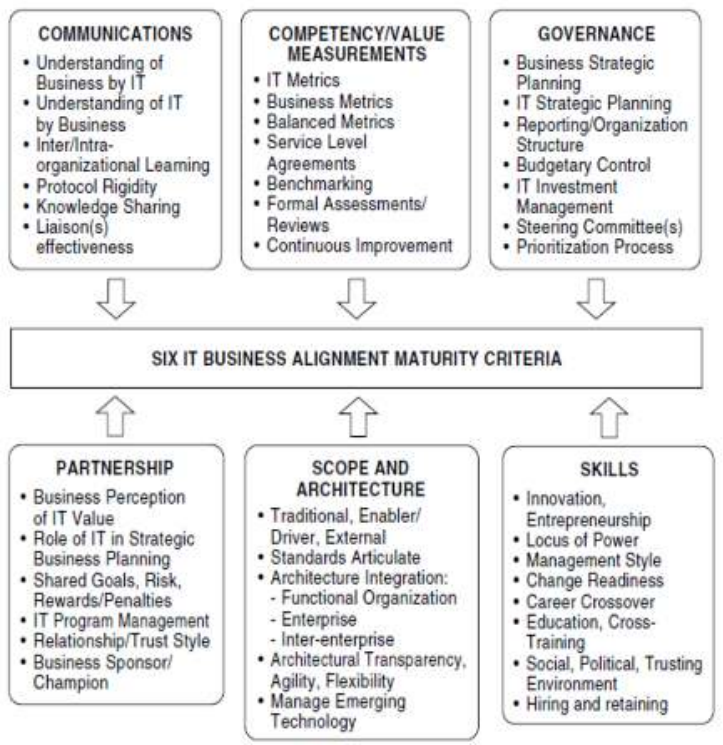

Gambar 3: Model penilaian strategi TI-Bisnis

Luftman membagi tingkat kematangan keselarasan strategi TI-bisnis ke dalam lima tingkatan, yaitu: a. Level 1 (Initial/ad hoc processes), b. Level 2 (Committed processes), c. Level 3 (Established processes), d. Level 4 (Improved, managed processes), e. Level 5 (Optimized processes).

\section{Metode}

Penelitian melibatkan 17 responden yang terdiri dari penentu kebijakan yaitu pejabat esselon 2, 3 dan 4 serta SDM yang terkait langsung dengan TI di BPPr \& KB.

Keluaran yang dihasilkan dari framework ini adalah berupa angka tingkat kematangan penyelarasan strategi sistem/teknologi informasi dan bisnis yang kemudian pada akhirnya akan dijadikan acuan untuk mengembangkan program yang digunakan untuk meningkatkan level keselarasan strategi Bisnis-TI, kemudian program yang dihasilkan tersebut akan divalidasi dan diuji coba praktikalitas dan efektifitasnya sehingga akan menghasilkan dokumen rencana kerja yang berisi program/kegiatan yang dapat dijadikan sebagai solusi untuk mencapai keselarasan strategi TI-Bisnis pada Badan Pemberdayaan Perempuan dan Keluarga Berencana beserta indikator keberhasilannya.

Langkah pengembangan yang dilakukan oleh peneliti adalah:

(1.) Tahap pengumpulan data. Tahapan penelitian ini diawali dari studi pustaka dari penelitian sebelumnya. Selanjutnya dilakukan observasi kondisi lingkungan TI/SI termasuk infrastruktur, aplikasi dan petugas TI. Proses wawancara dan penyebaran kuisioner dilakukan pada responden yang telah ditetapkan sebelumnya di Badan Pemberdayaan Perempuan dan KB. Hasil pengumpulan data ini dilengkapi dengan studi dokumentasi yang terkait pemanfaatan SI dan studi dokumentasi terhadap rencana strategi, visi, misi dan tujuan Badan Pemberdayaan Perempuan dan KB Provinsi Sumatera Barat.

(2.) Tahap Pengukuran Tingkat Kematangan Keselarasan strategi dan perencanaan Kebijakan Program. Hasil pengumpulan data akan dianalisis menggunakan SAMM-Luftman untuk memperoleh skala kematangan keselarasan strategi Sistem/Teknologi informasi-Bisnis.

Metode perhitungan kematangan yang digunakan dalam penelitian ini sama dengan metode yang digunakan oleh Yudha, Krisnadi dan Handoko dalam penelitian mereka. Setiap jawaban yang diberikan mencerminkan nilai kematangan dari setiap atribut. Jawaban responden untuk masing-masing atribut diwakili dengan nilai $1-5$. Perhitungan nilai kematangan atribut dihitung dengan merata-ratakan jumlah nilai kematangan dari jawaban responden.

Nilai Kematangan atribut $=\frac{\sum_{0}^{\mathrm{n}}(\mathrm{R})}{\mathrm{n}}$

Keterangan:

$\mathrm{n}=$ Jumlah responden

$\mathrm{R}=$ Nilai jawaban responden

Nilai kematangan untuk masing-masing area (total 6 area) mengacu pada model SAMM Luftman, dihitung dengan merata-ratakan atribut milik dari masing-masing area.

Nilai kematangan area $=\frac{\left.\sum_{0}^{\mathrm{n}} \text { (nilai kematangan area }\right)}{\mathrm{n}}$ Keterangan: 
$\mathrm{n}=$ Jumlah atribut untuk masing-masing area

Selanjutnya, nilai kematangan organisasi secara keseluruhan diperoleh dengan merata-ratakan seluruh atribut dari keenam area.

Nilai kematangan organisasi $=$ $\underline{\sum_{0}^{\mathrm{n}} \text { (Nilai kematangan area) }}$

\section{Keterangan:}

$\mathrm{n}=$ Jumlah area keselarasan strategi Luftman (ada 6 area)

Tingkat (level) kematangan dari atribut, area dan organisasi ditentukan dengan cara melakukan pembulatan ke bawah dari nilai kematangan ratarata yang dihasilkan.

(3.) Tahap pengembangan produk. Selanjutnya dapat disusun sebuah rancangan dokumen program/kegiatan sesuai dengan kondisi sekarang dan penyebab dari permasalahan yang ditemukan.

(4.) Tahap validasi dan uji coba. Kemudian dilakukan penyempurnaan dengan melakukan uji coba terhadap rancangan dokumen kebijakan program agar layak diterima dan digunakan nantinya.

Secara garis besar, uji coba dilaksanakan dua bagian. Bagian pertama uji coba untuk memvalidasi model program untuk penyelarasan strategi Bisnis-TI secara materi dan isi. Uji coba ini melibatkan ahli dari instansi yang memahami kebijakan. Uji coba bagian kedua adalah uji coba lapangan yang bertujuan untuk memvalidasi model program penyelarasan strategi Bisnis-TI secara empiris. Uji coba bagian kedua ini menggunakan pendekatan responden dengan menggunakan angket untuk menguji konsep produk yang terdiri dari uji praktikalitas dan uji efektifitas sebagai bahan utama untuk penyempurnaan konsep produk.

\section{HASIL DAN PEMBAHASAN}

Tingkat kematangan keselarasan strategi bisnis dan TI di BPPr \& KB secara keseluruhan berada pada level 1. Tabel 1 memperlihatkan nilai dan level masing-masing area dari total 6 area yang dilakukan penilaian berdasarkan model SAMM Luftman.

Keenam area yang dinilai berdasarkan kriteria model SAMM Luftman merupakan area-area yang berperan bagi organisasi dalam mencapai keselarasan strategi bisnis dan TI. Tingkat kematangan keselarasan strategi bisnis dan TI level 1 (Initial / ad-hoc) memiliki ciri sebagai berikut untuk masing-masing area penilaian. [10] (a.) Komunikasi bisnis dengan TI (KOM): kurang atau tidak adanya pemahaman antara satu sama lain (bisnis danTI).

(b.) Pengukuran nilai - manfaat dan kompetensi TI (PKN): pengukuan manfaat masih terbatas hanya pada beberapa faktor yang bersifat teknis.

(c.) Tata kelola TI (TKL): tidak ada proses yang bersifat formal, TI masih menjadi salah satu sumber pengeluaran bagi bisnis, penentuan prioritas dari insiatif-insiatif TI yang masih bersifat reaktif.

(d.) Kemitraan bisnis dengan TI (KMT): kualitas kemitraan yang minimal sehingga berpotensi pada konflik, TI masih dipandang sebagai pengeluaran dalam menjalankan bisnis.

(e.) Ruang lingkup dan arsitektur TI (RLA): tradisional (Cth: email, akuntansi, office).

(f.) Keahlian sumber daya manusia TI (SKL): TI masih menanggung sebagian besar risiko dengan isentif yang kecil, fokus pelatihan sumber daya manusia TI hanya pada faktor teknis.

Tabel 1: Nilai dan level masing-masing area

\begin{tabular}{|l|l|l|l|l|}
\hline No & Area & Label & Nilai & Level \\
\hline 1 & $\begin{array}{l}\text { Komunikasi Bisnis } \\
\text { dengan TI }\end{array}$ & KOM & 1.59 & 1 \\
\hline 2 & $\begin{array}{l}\text { Pengukuran nilai- } \\
\text { manfaat dan } \\
\text { kompetensi TI }\end{array}$ & PKN & 1.59 & 1 \\
\hline 3 & Tata Kelola TI & TKL & 1.45 & 1 \\
\hline 4 & $\begin{array}{l}\text { Kemitraan Bisnis } \\
\text { dengan TI }\end{array}$ & KMT & 1.78 & 1 \\
\hline 5 & $\begin{array}{l}\text { Ruang lingkup dan } \\
\text { arsirektur TI }\end{array}$ & RLA & 1.16 & 1 \\
\hline 6 & $\begin{array}{l}\text { Keahlian sumber daya } \\
\text { manusia TI }\end{array}$ & SKL & 1.94 & 1 \\
\hline $\begin{array}{l}\text { Nilai / Level Kematangan Strategi } \\
\text { Bisnis dan TI Organisasi }\end{array}$ & 1.58 & 1 \\
\hline
\end{tabular}

Dari hasil temuan di lapangan, terdapat 36 faktor penghambat keselarasan strategi bisnis-TI, yaitu:

1. Adanya kecenderungan pola pikir dimana TI melihat bahwa aspek bisnis sepenuhnya menjadi tanggung jawab bisnis saja, akibatnya TI cenderung pasif menunggu informasi terkait bisnis dari bisnis.

2. TI hanya memiliki pemahaman bisnis yang terbatas.

3. Bisnis hanya memiliki pemahaman bisnis yang terbatas terkait potensi dan kapabilitas TI

4. TI hanya memposisikan dirinya sebatas sebagai pendukung teknis bagi bisnis

5. Komunikasi yang terjadi antara bisnis dengan TI hanya terjadi ketika ada proyek atau insiatif bisnis tertentu 
6. Kurangnya insiatif TI untuk meningkatkan pemahamannya terhadap bisnis dan perannya untuk memberikan ide-ide dimana TI dapat mendukung sasaran dan prioritas bisnis

7. TI juga tidak berupaya menggali umpanbalik dari layanan TI secara formal dan terstruktur (dalam rangka pembelajaran).

8. TI cenderung dilihat (oleh bisnis) hanya sebagai alat pendukung teknis biasa

9. Pengetahuan masih cenderung terkotakkotak di masing-masing unit (bisnis \& TI).

10. Belum ada mekanisme formal dan terstruktur untuk mengelola pengetahuan sebagai aset.

11. Penghubung (liasion) yang menjembatani komunikasi bisnis dan TI hanya ada atau diadakan (tidak selalu) dalam kasus insiatif proyek tertentu dan bersifat temporer

12. Keberadaan penhubung (liasion), biasanya staf yang ditunjuk, hanya bersifat sebagai pembawa pesan (massenger) anatara bisnis dan TI, tidak memiliki peran strategis, juga memiliki pemahaman bisnis terbatas

13. Baik dari sisi bisnis dan TI masih belum memaham atau melihat peran strategis dari keberadaan penghubung (liasion) terkait dengan upaya untuk mencapai keselarasan strategi bisnis dan TI.

14. Fokus pengukuran kinerja TI hanya sebatas pda aspek teknis, bersifat minimal dan informal.

15. Bisnis masih cenderung melihat pengeluaran TI sebagai bagian dari pengeluaran operasional biasa.

16. Manajemen tingkat atas belum menjadikan TI sebagai prioritas utama.

17. Investasi TI mayoritas ditentukan oleh masing-masing unit bisnis (tidak melibatkan/sedikit melibatkan TI).

18. Keputusan investasi TI lebih kepeada pemenuhan ebutuhan bisnis jangka pendek (kebutuhan saat ini).

19. Pembuatan rencana strategi bisnis hanya melibatkan eksekutif bisnis dan tidak melibatkan peran serta dari TI.

20. TI masih belum memiliki strategi TI dalam rangka menentuka arsitektur dan standar bersifat umum mencakup lingkup organisasi.

21. Pembuata keputusan investai TI sepenuhnya menjadi wewenang manajemen bisnis (sedikit/tidak melibatkan peran TI).

22. Pengelola TI kurang membangun hubungan interpersonal yang baik dengan bisnis, sehingga bisnis hanya memiliki sedikit nformasi, kurang pemahaman akan peran strategis dan kemampuan TI untuk mendukung kemampuan bisnis.

23. Bisnis belum melihat TI mampu merealisasikan ide/gagasan yang bersifat inovatif dalam mendukung kinerja bisnis.

24. Batasan peran dan tanggung-jawabanatara bisnis dan TI yang masih belum jelas.

25. Bisnis melihat TI tidak mampu mengelola sumber-dayanya (fokus manajemen) dengan memaksimalkan perannya.

26. Masih kurangnya pemahamn bisnis terkait pentingnya standar dalam rangka integrasi.

27. Pihak menajemen bisnis level atas (pimpinan) merasa peran manajemen tingkat menengah belum maksimal dalam mendorong budaya inovasi dan kewirausahaan sampai ke level bawah. Sehingga sering timbul kesalahan presepsi atau ketisadaan motivasi dalam rangka mendukung kebijakan pimpinan. Hal tersebut berlaku di unit bisnis dan unit TI

28. Sudut pandang sumber daya manusia TI yang masih menitikberatkan hanya pada faktor teknis, sehingga merasa perannya hanya sebatas sebagai pendukung teknis bagi bisnis.

29. Kepala unit TI masih belum memilki program, inisiatif dan insentif khusus bagi para staf TI-nya alam rangka menumbuh kembangkan, mendorong kesadaran akan budaya inovasi dan semangat kewirausahaan.

30. Kecenderungan kurangnya inisiatif dari kepala unit (termasuk pengelola TI) untuk mau berpartisipasi / telibat langsung (ikut bertanggung jawab) terkait dengan perumusan keputusan / kebijakan.

31. Belum adanya program atau insentif khusus yang bersifat formal dan jelas unuk mendorong inisiatif partisipasi dan tanggung jawab dari kepala unit (termasuk unit TI) terkait dengan pembuatan keputusan/kebijakan.

32. Tidak adanya karir lintas fungsi yang bersifat formal atau upaya untuk menumbuh kesadaran terhadap manfat dari program tersebut, juga masih belum adanya insentif khusu yang bersifat formal terkait prsonil yang memiliki kualitas pemahaman bisnis dan TI yang baik.

33. Tidak adanya program pelatihan lintas fungsi yang bersifat formal atau upaya untuk menumbuh kesadaran terhadap manfat dari program tersebut, juga masih belum adanya insentif khusus yang bersifat formal terkait prsonil yang memiliki kualitas pemahaman bisnis dan TI yang baik.

34. Masih belum adanya program formal atau isentif khusus yang brsifat formal yang 
mengarahkan pada lingkungan kerja yang bersifat kemitraan antara bisnis dan TI.

35. Keterbatasan pemahaman dari sisi bisnis yang melihat bahwa kapabilitas TI organisasi dapat dibangun hanya mengandalkan kemampuan teknis yang tinggi.

36. Belum adanya program atau insentif formal yang mendorong pada motivasi inisiatif terkait pemahaman bisnis oleh TI.

Selanjutnya dalam rangka membuat produk, ketiga puluh enam penghambat BPPr \& KB tersebut dicari hubungan relasionalnya dengan faktor-faktor penghambat hasil penelitian Luftman.

Dasar pembuatan hubungan relasional tersebut adalah hubungan sebab-akibat yang relevan dengan kondisi BPPr \& KB antara faktor-faktor penghambat $\mathrm{BPPr} \& \mathrm{~KB}$ yang telah teridentifikasi dengan fakor-faktor penghambatan isu utama TI hasil penelitian sebelumnya. Hubungan relasional dengan hasil penelitian sebelumnya juga memastikan agar penulis dapat memperoleh gambaran yang lebih lengkap dan mendetail terhadap faktor-faktor penghambat yang telah di identifikasi pada BPPr \& KB. Hingga pada akhirnya dapat menjadi acuan bagi penulis untuk memberikan rancangan program yang lebih terfokus.

Pembuatan rancangan program sebagai bentuk produk untuk ketiga puluh enam faktor-faktor penghambat yang telah ter-identifikasi di BPPr \& $\mathrm{KB}$ didasarkan pada hasil hubungan relasional dengan faktor-faktor penghambat dan berdasarkan kata kunci dari masing-masing faktor penghambat dan hasil uji coba model rancangan program yang telah direvisi, sehingga didapatkan 42 rekomendasi program/kegiatan yang dapat dilaksanakan oleh BPPr \& KB dalam rangka meningkatkan level keselarasan strategi Bisnis-Ti nya.

Validasi diperlukan untuk menguji keefektifan dari produk telah dihasilkan. Secara rasional, validasi juga digunakan untuk menilai produk dapat meningkatkan keselarasan strategi TI-bisnis. Produk ini di validasi oleh $\mathrm{Kabid} / \mathrm{Kadis}$ yang bertindak sebagai validator. Setelah itu produk di uji coba kepada responden.

Uji Coba Validasi Konsep Program untuk Penyelarasan Strategi Bisnis-TI dilakukan secara materi dan isi

Uji coba yang dilakukan pertama kali adalah tinjauan materi dan isi oleh ahli materi. Uji coba digunakan untuk mencari informasi sebagai dasar meningkatkan kualitas produk terkait dengan kedalaman materi dan kebenaran konsep. Hal ini dilihat dari ketepatan materi, dan saran-saran perbaikan yang disampaikan. Sehingga diambil kesimpulan kelayakan produk secara teoritis.

Ahli materi pada konsep produk ini adalah 1 (satu) orang praktisi TI yang berkualifikasi pendidikan Strata 2 (S2) Chief Information Officer yang benar-benar memahami penyelarasan strategi Bisnis-TI.

Ahli yang memvalidasi konsep rancangan program penyelarasan strategi Bisnis-TI secara isi adalah Top Level manajemen pada Badan Pemberdayaan Perempuan dan KB. Ahli pada konsep ini adalah ahli dalam menetapkan kebijakan sesuai dengan jabatan dan kewenangannya.

Ahli secara isi ini terdiri dari 2 (dua) orang yaitu kepala badan dan kepala bidang data dan informasi. Beliau adalah orang yang sangat memahami proses bisnis yang terjadi pada instansi dengan latar belakang pendidikan S2 Manajemen.

Uji Coba Validasi Konsep Program Penyelarasan Strategi Bisnis-TI secara empiris meliputi:

(a.) Uji Coba Praktikalitas

Berdasarkan perhitungan persentase diketahui bahwa uji praktikalitas model program untuk penyelarasan strategi Bisnis-TI untuk kategori sangat praktis tertinggi terdapat pada pernyataan model yang diajukan telah mengandung elemenelemen yang dibutuhkan dalam menyelaraskan strategi Bisnis - TI, dengan persentase sebesar $84 \%$.

Dari uji praktikalitas pada prinsipnya secara persentase sudah memenuhi unsur sangat praktis dan praktis, namun pada nilai-nilai yang terdapat pada pernyataan dirasakan masih ada kelemahan terhadap rancangan produk yang ditawarkan.

Secara umum uji praktikalitas dari produk rancangan program ini berada pada kategori sangat praktis dengan pesrsentase $80 \%$. Artinya rancangan program sangat praktis untuk dimanfaatkan pada Badan Pemberdayaan Perempuan dan Keluarga Berencana Provinsi Sumatera Barat untuk penyelarasan strategi Bisnis-TI.

(b.) Uji Coba Efektivitas

Uji coba efektivitas konsep rancangan program untuk penyelarasan strategi bisnis-TI dilakukan untuk menguji persepsi responden tentang keefektifan rancangan program untuk diterapkan pada BPPr \& KB.

Efektifitas produk rancangan program untuk penyelarasan strategi Bisnis-TI ini dihitung berdasarkan interval persentase berdasarkan data 
mentah uji efektivitas yang dikumpulkan menggunakan skala Likert.

Berdasarkan perhitungan tersebut diketahui bahwa uji efektivitas produk rancangan program untuk penyelarasan strategi Bisnis-TI

Dari uji efektivitas pada prinsipnya setiap pernyataan secara persentase sudah memenuhi unsur sangat praktis dan praktis, namun pada nilai-nilai yang terdapat pada pernyataan dirasakan masih ada kelemahan-kelemahan terhadap rancangan produk yang ditawarkan.

Secara umum uji efektivitas dari produk rancangan program penyelarasan stategi Bisnis-TI ini berada pada kategori sangat efektif untuk diimplementasikan pada instansi BPPr \& KB. Implementasi rancangan program ini efektif untuk diaplikasikan demi tercapainya efektivitas dan efisiensi penyelarasan strategi Bisnis-TI Badan Pemberdayaan Perempuan dan Keluarga Berencana Provinsi Sumatera Barat.

\section{KESIMPUlaN}

Dari hasil penelitian dan pembahasan sebelumnya dapat disimpulkan sebagai berikut:

1. Tingkat kematangan keselarasan strategi Bisnis dan TI Badan Pemberdayaan Perempuan dan Keluarga Berencana Provinsi Sumatera Barat berada pada level 1 (nilai rata-rata 1,58). Luftman menyebutkan bahwa organisasi yang berada pada level 1 (initial/ad-hoc) berarti masih belum memiliki/mengaplikasikan keselarasan strategi bisnis dan TI sama sekali

2. Rancangan program bagi BPPr \& KB mengacu pada 6 area keselarasan Luftman, secara umum mencakup: komunikasi bisnis dengan TI yang lebih baik, pengukuran manfaat dan kompetensi TI yang lebih terintegrasi dengan bisnis, penerapan tata kelola TI yang efektif, kemitraan bisnis dengan TI yang terkelola, perencanaan ruang lingkup dan arsitektur TI yang ter-standarisasi dan terintegrasi, serta sumber daya manusia TI yang berkompeten.

3. Penelitian ini menghasilkan Rencana Kerja Tahunan yang berisi program/kegiatan yang dapat diimplementasikan oleh BPPr \& KB dalam menyelaraskan strategi Bisnis-TI

\section{DAfTAR PUStaka}

[1] Boar B. H. 2001. The Art of Strategic Planning for Information Technology 2nd Edition. New York: John Wiley \& Sons Inc.Turban E, \& Volino L. 2011. Information Technology for
Management $8^{\text {th }}$ Edition. New Jersey. John Wiley \& Sons Inc

[2] Boar B. H. 2001. The Art of Strategic Planning for Information Technology 2nd Edition. New York: John Wiley \& Sons Inc.Turban E, \& Volino L. 2011. Information Technology for Management $8^{\text {th }}$ Edition. New Jersey. John Wiley \& Sons Inc

[3] Boar B. H. 2001. The Art of Strategic Planning for Information Technology 2nd Edition. New York: John Wiley \& Sons Inc.Turban E, \& Volino L. 2011. Information Technology for Management $8^{\text {th }}$ Edition. New Jersey. John Wiley \& Sons Inc

[4] Krismadinata, K., Arnovia, Y., Syahril, S., \& Yahfizham, Y. (2018). Kontribusi Ekspektasi Kinerja, Usaha, Faktor Sosial dan Fasilitas Terhadap Sikap Operator Sistem Informasi. Jurnal Teknologi dan Sistem Informasi, 4(1), 44-52.

[5] Boar B. H. 2001. The Art of Strategic Planning for Information Technology 2nd Edition. New York: John Wiley \& Sons Inc.Turban E, \& Volino L. 2011. Information Technology for Management 8th Edition. New Jersey. John Wiley $\&$ Sons Inc

[6] Luftman J. N, 2003. Assessing IT-Bussiness Alignment Information System Management. 20 (4), 9-15

[7] Hosseinbeig S, Moghadam D. K, \& Vahdat. 2012. IT Strategic Alignment Maturity and IT Governance. IEEE, p.67-72

[8] J.C. Handerson, N. Venkatraman. 1990. Strategic Alignment: A Model for Organizational Transformation via Information Technology, Center for Information System Research. Massachusetts Institute of Technology Sloan School of Management. Massachusetts

[9] J. Luftman. 2000. Assesing Business-IT Alignment Maturity, Communications of The Association for Information System. Vol.4, No.1

[10] J. Luftman. 2003. Competing in The Information Age: Align in the Sand. 2nd Edition. Oxford University Press. New York

\section{Biodata Penulis}

Ruri Juswira, lahir di Padang, 8 Januari 1984. Sarjana Teknik Informatika dari Institut Teknologi Padang, lulus 2007. Tahun 2018 memperoleh gelar Magister Chief Information Officier Universitas Negeri Padang. Aparatur Sipil Negara pada Dinas Pemberdayaan Perempuan dan Perlindungan Anak Provinsi Sumatera Barat dari tahun 2010 sampai saat sekarang. 